Editorial

\title{
"Producing People" in Documents and Meetings in Human Service Organizations
}

\author{
Malin Åkerström ${ }^{1, *}$ and Katarina Jacobsson ${ }^{2}$ \\ ${ }^{1}$ Department of Sociology, Lund University, 22100 Lund, Sweden; E-Mail: malin.akerstrom@soc.lu.se \\ 2 School of Social Work, Lund University, 22100 Lund, Sweden; E-Mail: katarina.jacobsson@soch.lu.se \\ * Corresponding author
}

Submitted: 28 January 2019 | Published: 28 February 2018

\begin{abstract}
This thematic issue is devoted to how human service work may be influenced by accentuated administrative processes, as well as reinforced by digitalization, in contemporary society. The public sector has expanded the requirements of documentation, auditing and evaluation practices. Policy, problems and persons are shaped and enacted in meetings and documents. Meetings and documents comprise the forum for making highly important decisions for the individual client or for various categories of clients. Still, people's participation in meetings and their reading and production of documents are often overlooked in studies of human service organizations. In this thematic issue, empirically-oriented researchers describe and analyze human service workers' administrative routines, particularly focusing on processes of client inclusion and exclusion.
\end{abstract}

\section{Keywords}

administration; clients; digitalization; documents; field interaction; human service organization; meetings; professionals

\section{Issue}

This editorial is part of the issue "'Producing People' in Documents and Meetings in Human Service Organizations", edited by Malin Åkerström (Lund University, Sweden) and Katarina Jacobsson (Lund University, Sweden).

(C) 2019 by the authors; licensee Cogitatio (Lisbon, Portugal). This article is licensed under a Creative Commons Attribution 4.0 International License (CC BY).

\section{Introduction}

An increasing proportion of working hours in many organizations is devoted to administrative tasks. In a number of studies of the public sector expanding requirements of documentation, auditing, and evaluation practices are investigated, discussed, and often critiqued. Technological advances reinforce the administrative escalation. Digital aids are used for information exchange and data gathering both for staff and patient: from dementia prevention apps and "doctors on-line" to electronic records systems or even more comprehensive digital systems. The increase of digital "tools" in human service organizations is sometimes captured in the term "welfare digitalization" (Jacobsson \& Martinell Barfoed, 2019). Digital infrastructures enable large, wide-ranging data collections that can easily be transferred, processed, and transformed into numbers, tables, and graphs. Simultaneously, opportunities for evaluation and control are increasing: "What help, advice, or assistance is offered at the social service offices or emergency rooms? To whom and how often"? The work and effort of feeding these kinds of data to the digital systems are often time-consuming and sometimes technically challenging. Overall, administration is assumed to take time and commitment from what various professions believe is the core of their business (Forssell \& Ivarsson Westerberg, 2014; Kello, 2015). Researchers are concerned that this development can lead to a de-professionalization (e.g., Evetts, 2009).

Several collaborative tendencies are believed to have paved the way for this development. New control mechanisms, as well as management methods in the public sector have been collected in terms such as New Public Management (Hood, 1991), Audit Society (Power, 1997), 
and the Administration Society (Forssell \& Ivarsson Westerberg, 2014). A parallel trend is the introduction of a socalled evidence-based practice in, most notably, health care and social work, promoted by the evidence movement, (e.g., Bohlin \& Sager, 2011).

While this change is often explained as driven by pressure from above, we would claim that there are also self-generating forces, what Simmel (1978) referred to as Eigendynamik. We assume that successful dissemination of new administrative approaches can not only be explained by economic and ideological means of government from the state authorities. These self-generating forces may be seen in that meetings and documents are so closely linked as if they presuppose each other: meetings generate both new meetings and documents, documents generate both new documents and meetings. Furthermore, several researchers have observed the presence of meeting chains and document chains, which are initiated by the members themselves (Åkerström, 2019; Schwartzman, 1989). It is reasonable to assume that a social psychological aspect also plays a part, harbored in the administration's enticements and attraction. Such appeals are evident in internal processes such as opportunities for influence, collegial interaction, and demonstrated competence (e.g., Martinell Barfoed \& Jacobsson, 2012)-often performed with great emotional involvement.

Regardless of what this development is called, a practical consequence is that administration's two main ingredients - meetings and documents-are now accentuated in new ways: new meeting forms are being developed and refined in the meetingization process characterizing contemporary society (Hall, Leppänen, \& Åkerström, 2019; van Vree, 2011), documentation is specialized, often in digital forms (Jacobsson \& Martinell Barfoed, 2019). Policy, problems, and persons are shaped and enacted in meetings and documents. Meetings and documents comprise the forum for making decisions that might be highly important for the individual client or for various categories of clients. Still, people's participation in meetings and their reading and production of documents are often overlooked in studies of human service organizations. Furthermore, among professionals, these administrative tasks are often complained about and portrayed as the bureaucratization of human service work (e.g., Goldman \& Foldy, 2015).

The social organization of human service work takes place in the office setting, not solely, or even most often, in encounters with clients. Whenever human service workers engage in a client case, they access an existing file or create a new one. Past records should offer convincing interpretations of current behaviors and circumstances. It is through text-mediated human service work that the case becomes visible (Prior, 2003). Cases are "talked into being"-people are produced (cf. Holstein, 1992) - in meetings and case conferences. Human service workers' tasks become visible through paperwork and meetings, and thus, accountable; that is, accounts are formulated for both the client and the work performed. Nonetheless, some dimensions of human service and of the clients' narrated lives or conditions might be omitted or implicitly taken for granted.

\section{Contributions}

This thematic issue is devoted to how human service work may be influenced by the accentuated administrative processes in contemporary society. Researchers were invited to describe and analyze human service workers' administrative routines, particularly focusing on processes of client inclusion and exclusion. Different empirical cases are presented and analyzed. Most of the contributions concern human service workers' everyday administrative routines, and how they manage documents and meetings. A few contributions illustrate the contrast between interactions in a field setting with formulations in documents, administrative routines, or interactions in an office setting.

The topic we deal with in this thematic issue holds a number of relevant questions, for instance: how are provisions of care or definitions of problems "talked into being" and textualized in documents? Which clients are assigned to the "outside" and which are invited "inside"? How do meetings and paperwork interact in constructing client descriptions, social problems, solutions, and human service professionalism? In this issue, the problem of digitalized working methods runs like a ubiquitous thread through the practices of fitting clients' problems or staff's efforts into administrative routines. Human service staff paints a picture of how they sometimes engage in efforts of beating the systems, but mostly they criticize or exemplify how they are ruled by various electronic systems.

In these articles, there are many illustrations of how human service workers are disciplined by new ways of meeting and/or documenting. Consider the surveillance and regulating ways described in detail in the description by Hjärpe (2019) of the "pulse meetings" in a Swedish social work setting. The staff is required to meet regularly in front of a whiteboard:

Every morning at 8 am, five work teams gathered around five whiteboards for a 15-minute meeting, standing on their feet. One manager explained: 'Sitting down would make the staff too comfortable' (Hjärpe, 2019, p. 188)

The study explores a number-based comparative logic where the social workers collectively compare their work in terms of how many cases they have handled. The numbers are seen as "productivity", as performance measures, but some staff engages in negotiations concerning the meaning and interpretation during interaction moments, and others convince managers to make changes in terms of what numbers to count.

Another disciplining trend in social work is the efforts of standardization, which in itself has a long history 
in society (Busch, 2011). Studies of standardization-ininteraction (Maynard \& Schaeffer, 2006) analyze the performance of the standard, the actions and interactions of the parties involved. Critics have found that the rigidities of standardization may lead to awkward interactions (Suchman \& Jordan, 1990). Such difficulties can be seen in Martinell Barfoed's (2019) article. It is an illustration of how clients are constructed in the era of standardization, where Swedish social workers have to follow questionnaires in a uniform way, excluding possibilities of nuances. Furthermore, the technical changes through digitalization have given rise to the remarkable phenomenon of a digitally constructed client story.

Devlieghere and Roose's (2019) article also discusses digitalization but from the intersection of, at times, conflicting demands that human service workers currently face, namely transparency-that is, increased client participation and use of electronic information systems.

Transparency, in this Belgian child welfare context, concerns showing what is happening on the ground towards a diversity of organizations and people, including service users, colleagues, legislative bodies and the broader society. As only data submitted to the electronic system counts as relevant data, staff discovers how to circumvent the system. Paradoxically, the "transparency system" brings haziness to such cases.

Another dilemma is illustrated by Thedvall (2019) in her article on collaboration between municipal and state agencies (the Public employment agency and the Social services), and human service workers' efforts to transfer people through documents. The Swedish case she studied concerns an "activation policy" aiming to get people into work with the help of an instrument consisting of four separate documents. The four documents were constructed for assessing problems and suggesting plans for the future, and they were supposed to fit like cogs in an efficient process, filled in by the various staff at the different organizations, one after the other. It turned out that this process lacked the flow one had aimed for. One interviewee explained that they had hoped for a smooth routine when they mapped it out in a simple and logical way, but this "was one and a half years ago, she said, and since then we have been working to make it operational" (Thedvall, 2019, p. 223). During meetings, some of the problems were identified and resolved; meetings in this case functioned as "smoothing machines".

Meetings and documents interact in several ways, and Archer-Kuhn and de Villiers (2019) illustrate yet another in their investigation. They researched a professional development course in Canada, organized as a workshop meeting on how child protection service workers respond to domestic violence. The problem to be addressed was the tendency that mothers are singlehandedly held accountable for their children's welfare in such situations. Once gender norms were discussed and reflected on, according to this study, the child protection workers reported that they no longer wrote statements in the agency files to implicate mothers as solely respon- sible for child protection and that they include information about the father in the agency database.

Broerse (2019) investigates an aspect of integration work, namely a sport-based settlement service targeting newly arrived migrants in Melbourne, Australia, with a focus on staff meetings and productions of documents. These bureaucratic practices can have a profound impact on client categories and consequences for processes of exclusion/inclusion in these programs. At times, staff made efforts to beat the system by finding alternative solutions for some clients. In order to include more clients to the program, the "official system" could be circumvented by including a non-eligible client in the volunteer program instead, thereby avoiding registering the client in the electronic system.

\section{Contrasting Cases: Interactions in a Setting}

In the last two articles, interactions with clients are more visible. Wästerfors' (2019) article concerns the contrast between "writing practices" and re-narrated violent, multifaceted events in a Swedish juvenile center. It illustrates the complexities of clients' troubles and interactions between youngsters and staff, and how these are circumscribed and reduced in institutional journals, assessments, and case files. The casebook journal offers truncated versions, leaving out the involved youngsters' moral analyses, and seldom a fully understandable prequel regarding the events. In the journals, events might be summarized as, for instance, "before dinner, there is a fight on the TV sofa" (Wästerfors, 2019, p. 250), whereas the youngsters may account for who began and the prehistory of what is summarized as a "fight". Casebook journals are made up of running notes on care and surveillance that form material for upcoming placements and treatment programs. The writing method in institutions employs an individualizing gaze, depicting young people in care as troublesome clients, which will inevitably produce the "finding" that these are especially distressed individuals. As for conversations among themselves or with the field observer, staff does narrate alternative variants of conflict accountability, as well as address the institutional and social qualities of the narrated event. It is the written case book journals that do not seem to permit such interpretations.

The last article in this thematic issue is Emerson and Pollner's (2019) text, based on his and the late Melvin Pollner's work on American psychiatric emergency teams from the 1970s. More specifically, they studied social control decision-making in the field, illustrating the contrast between office work and in-the-field work settings. In the latter, interactions tend to become open, unpredictable, and at times even wild. In the office, client meetings take place on the human service workers' "home turf", and ensure, by its atmosphere, a ceremonial social control. Most of our contributions in this thematic issue tell about today's standardized form-filling activities that human service workers are engaged in. Emerson 
and Pollner's article provides a dramatic contrast with the far less scripted interactions they illustrate. Here, human service workers in the neighborhood find themselves in a rather different office: negotiations take place in apartment corridors or office hallways, with the assistance of "capable guardians" or witnesses, such as concerned family members, friends, neighbors or landlords. On the client's turf, human service workers cannot rely on office routines or standardized documents but have to be skillful in gaining access to clients and their homes, "read" and adjust to present circumstances, and use situationally-sensitive practices, staying open for changing strategies momentarily.

We appreciate this last article most of all for illuminating these specific interactions and the contrast to office work, but also because it can stand as a model for other researchers: the gains of keeping and recycling "old data" (Wästerfors, Åkerström, \& Jacobsson, 2014). Most qualitative researchers have projects where the empirical material may be old, but the analytic problems remain. In a research policy climate where funders insist on new and fresh data and references, it is worth remembering that much of our data harbor analytical puzzles that are more or less timeless.

\section{Concluding Remarks}

In this thematic issue, we have strived to capture a variety of fields and situations where people production occurs - often with the help of forms, digital tools, electronic systems, and different kinds of meetings. We have included studies from various parts of the world, illustrating how staff have to use standardized digital tools, but also ways in which human service workers engage in ways of getting around them. Furthermore, we have included contributions revealing the contrast to "deskwork" with work in the field or specific settings. We are thankful to the authors for making this variety possible.

\section{Acknowledgments}

In addition to our gratitude to the contributors, we would also like to thank the many competent and thorough reviewers who have been involved. As many as 29 individual reviewers have commented on our eight manuscripts, encouraging the authors to improve their articles further. Each manuscript has been reviewed by at least three, most often four, anonymous reviewers before our own final review.

\section{References}

Åkerström, M. (2019). The merry-go-round of meetings: Embracing meetings in a Swedish youth care project. Sociological Focus, 52(1), 50-64.

Archer-Kuhn, B., \& de Villiers, S. (2019). Gendered practices in child protection: Shifting mother accountability and father invisibility in situations of domestic vi- olence. Social Inclusion, 7(1), 228-237.

Bohlin, I., \& Sager, M. (2011). Evidensens många ansikten [The many faces of "evidens"]. Lund: Arkiv.

Broerse, J. (2019). "How do we put him in the system?": Client construction at a sport-based migrant settlement service in Melbourne, Australia. Social Inclusion, 7(1), 238-247.

Busch, L. (2011). Standards: Recipes for reality. Cambridge, MA: MIT Press.

Devlieghere, J., \& Roose, R. (2019). Documenting practices in human service organisations through information systems: When the quest for visibility ends in darkness. Social Inclusion, 7(1), 207-217.

Emerson, R., \& Pollner, M. (2019). Contingent control and wild moments: Conducting psychiatric evaluations in the home. Social Inclusion, 7(1), 259-268.

Evetts, J. (2009). New professionalism and new public management: Changes, continuities and consequences. Comparative Sociology, 8(2), 247-266.

Forssell, A., \& Ivarsson Westerberg, A. (2014). Administrationssamhället [The administrative society]. Lund: Studentlitteratur.

Goldman, L., \& Foldy, E. (2015). The space before action. Social Service Review, 89, 166-202.

Hall, P., Leppänen, V., \& Åkerström, M. (2019). Mötesboken- analyser av arbetslivets sammanträden och rosevinsmingel [Meetings: Analyzes of formal meetings and mingling sessions]. Malmö: Egalité.

Hjärpe, T. (2019). Social work on the whiteboard: Governing by comparing performance. Social Inclusion, 7(1), 185-195.

Holstein, J. A. (1992). Producing people: Descriptive practice in human service work. Current Research on Occupations and Professions, 7, 23-39.

Hood, C. (1991). A public management for all seasons? Public Administration, 69(1), 3-19.

Jacobsson, K., \& Martinell Barfoed, E. (2019). Socialt arbete på pränt. Dokumentation och digitalisering $i$ socialtjänsten [Social Work by the computer: Documentation, digitalisation and paper work]. Malmö: Gleerups.

Kello, J. (2015). The science and practice of workplace meetings. In J. Allen, N. Lehmann-Willenbrock, \& S. G. Rogelberg (Eds.), The Cambridge handbook of meeting science (pp. 709-734). New York, NY: Cambridge University Press.

Martinell Barfoed, E. (2019). Digital clients: An example of people production in social work. Social Inclusion, 7(1), 196-206.

Martinell Barfoed, E., \& Jacobsson, K. (2012). Moving from 'gut feeling' to 'pure facts': Launching the ASI interview as part of in-service training for social workers. Nordic Social Work Research, 2(1), 5-20.

Maynard, D. W., \& Schaeffer, N. C. (2006). Standardization-in-interaction: The survey interview. In P. Drew, G. Raymond, \& D. Weinberg (Eds.), Talk and interaction in social research methods (pp. 
9-27). London: Sage.

Power, M. (1997). Audit society: Rituals of verification. Oxford: Oxford University Press.

Prior, L. (2003). Using documents in social research. London: Sage.

Schwartzman, H. (1989). The meeting. Boston, MA: Springer.

Simmel, G. (1978). The philosophy of money. London. Routledge.

Suchman, L., \& Jordan, B. (1990). Interactional troubles in face-to-face survey interviews. Journal of the American Statistical Association, 85, 232-241.
Thedvall, R. (2019). Blend gaps through papers and meetings? Collaboration between the social services and jobcentres. Social Inclusion, 7(1), 218-227.

van Vree, W. (2011). Meetings: The frontline of civilization. The Sociological Review, 59(1), 241-262.

Wästerfors, D. (2019). Things left unwritten: Interview accounts versus institutional texts in a case of detention home violence. Social Inclusion, 7(1), 248-258.

Wästerfors, D., Åkerström, M., \& Jacobsson, K. (2014). Reanalysis of qualitative data. In U. Flick (Ed.), The Sage international handbook of qualitative data analysis (pp. 467-480). London: Sage.

\section{About the Authors}

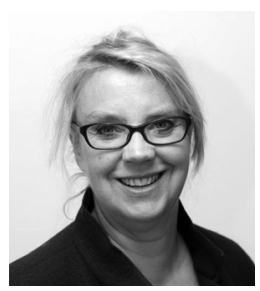

Malin Åkerström is Professor of Sociology at Lund University, Sweden. Her research focuses on ethnographic studies of social control and deviance. Her most recent book is Suspicious Gifts: Bribery, Morality, and Professional Ethics (Transaction), and her current project concerns meetings in working life. She has published articles in Sociological Focus, Social Problems, Symbolic Interaction and Sociological Perspective.

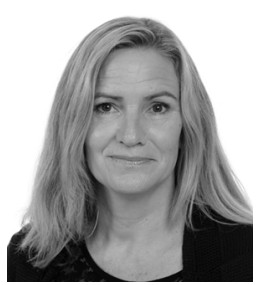

Katarina Jacobsson is Professor at School of Social Work at Lund University, Sweden. Her research areas include the sociology of knowledge, social control, sociology of deviance, accounting practices, qualitative methodology. Current projects include: a) documenting practices in health care and social services; b) judicial and medical decision-making; c) evidence-based social work in practice; and d) quality in qualitative methods. She has published in various journals such as Deviant Behavior, European Journal of Social Work, and Qualitative Research. 